\title{
UIT EEN OUD DAGBOEK
}

\author{
DOOR
}

TH. B. VAN LELYVELD

AANKOMST IN SURINAME

(3 Dec. 1894)

't Is vier uur in den ochtend.

In de diaphane duisternis wiegelt de „Prins Frederik Hendrik”, stoomend met halve vaart, op den rustig deinenden Oceaan.

De boot schijnt moe en loom na den langen tocht over hoog opgolvend, woelend, eindeloos water. Uit den ijzeren schoorsteen spreidt de rookpluim zich langzaam krullend achterwaarts.

$\mathrm{Nu}$ slingert op het loodbordesje de bootsman, gesteund door een broeking om zijn middel, met regelmatige tusschenpoozen het dieplood ver in het klotsend water. Regelmatig galmt hij de vademdiepte naar de brug, waar af en toe een kort commando klinkt.

Hoog boven in den grooten mast spiedt de uitkijk; hij zoekt het vonkje van het lichtschip, dat ver in het duister geankerd is voor de monding der Suriname-rivier.

$\mathrm{Er}$ is nog niets te zien.

Dan snort plotseling fel sissend een vuurpijl uit de boot recht de hoogte in naar den nog donkeren hemel.

Om half zes doemt in het Oosten een vaag rood schijnsel op; het wordt grooter, het wordt glanzend als robijn, het wordt steeds lichter, al lichter. Totdat een albeheerschend, goudstralend morgenlicht gulden glimpjes toetst op de kruivende toppen van het immense, deinende watervlak.

In enkele oogenblikken is de zon meester van den dag geworden. Onder den egaal kobalten hemel is de zee bezaaid met al maar dansende schittering. Doch de zee heeft sinds gisteren haar doorschijnend ultramarijnen mantel afgelegd; zij is geelgroenig van kleur geworden door al het meegestuwde leem en de fijne humusstoffen van de Amazone, Marowijne en andere Zuid-Amerikaansche stroomen. 
Het detachement suppletietroepen hangt, kalm turend, over de reeling van het voordek. Verlangend kijken allen naar den horizon, waarachter zij het nieuwe land zoeken dat zij dienen gaan, ieder met zijn eigen verwachtingen.

Eensklaps, als opgeschrikt, wijst er een met uitgestrekten arm naar een wazig, nauw merkbaar lijntje aan den einder. Men stoot elkaar aan, men wijst opnieuw, allen zien nu het dun donker streepje. Er is blijdschap en druk gepraat.

Door de vele ondiepten kan de boot niet den kortsten weg volgen, zij koerst in oostelijke richting, om daarna in een grooten boog de betonde vaargeul te volgen naar de monding der Suriname-rivier.

Om half acht wordt het ongeveer 10 K.M. van Braamspunt gestationneerde lichtschip gepasseerd; we zien er de eerste negers die ons schreeuwend toewuiven.

Dan komt de loods aan boord.

't Is prachtig, stil, niet te warm weer, opwekkend is de koele morgenbries. Maar zóó violent is het lichtgeschitter op de zee, dat de oogen het moeilijk verdragen.

Nog vóór het land bereikt is, komen zwart gevlekte, emeraldgroene kapellen aangefladderd; ook enkele vogels, libellen en zelfs wespen vertellen de eerste verhalen van vreemde boomen en nog ongekende hloemen.

Een half uur later stoomt de boot, bij Braamspunt, langs een dichte mangrove-vegetatie, waarvan de warrelende, zware luchtwortels, diep grijpend in de bruine modder, de trouwe verdedigers zijn van de kust.

We zijn nu in de riviermonding, maar deze is zóó breed, dat het invaren onmerkbaar plaats heeft. De bosschen worden nu wat duidelijker, totdat het groen der machtige boomen een weldadige sensatie schenkt.

Om half negen worden, op de plaats waar de Commewijne in de Suriname-rivier valt, eerst het quarantarie-station Post Leijden en dan het fort Nieuw-Amsterdam bereikt. Maar het fort toont niets dreigends, integendeel, haast idyllisch ligt het tusschen hooge palmenkruinen en het weelderig gebladerte van manja-boomen. Riant plekken de witte woningen tegen den donkeren achtergrond van diep groen. Het zwaar geschut kijkt slaperig hier en daar over de borstwering, maar vroolijk waaiert de Nederlandsche driekleur aan den hoogen vlaggestok.

De boot stopt, er moet kruit worden gelost.

In een groote overdekte tentboot, geroeid door inlandsche sol- 
daten, komt de fortconmandant aan boord. Deze artilleriecollega is in wit pak gekleed en gewapend met een dito parasol.

Een uur later wordt verder gestoomd, behoedzaam, want 't is jong vloed, en dan is, zegt men, de bank vóór de plantage Jagtlust, niet ongevaarlijk.

De vaart door de breede rivier met haar lage oevers is, door tal van wisselende gewaarwordingen, een en al verrukking. Het zich verplaatst voelen in een nieuwe wereld, het voorbij gaan van plantages, waar bewoners vriendelijk wuiven met de zakdoek, het nu aanbrekend nieuwe leven vol stoute verwachtingen, dit alles en meer, doet het gemoed beven van geluk en van volmaakte vrede.

Bij een draai van een bocht, kijk, daar is rechts Paramaribo te zien; men wijst ons den toren van de Katholieke kerk, het torentje van het Finantie-gebouw, de vlag die wijduit wappert van het fort Zeelandia.

Als we dit langzaam voorbij stoomen boemt het mailschot aan boord; het wordt onmiddellijk door het fort beantwoord.

$\mathrm{Nu}$ verschijnt, achter een zeer ruim grasveld-plein, dat omzoomd is door statige koningspalmen, het blanke Gouvernementsgebouw; dan is er de Waterkant met het groen van wijdarmige amandelboomen; een bonte menigte krioelt langs de wit geverfde koopmans woningen.

Vroolijk is de aankomst aan de pier.

De douane komt aan boord tegelijk met een stroom van menschen in lichte, tropische kleeding. Er wordt omhelzend en handendrukkend verwelkomd, er is veel gevraag en druk gepraat.

Onder geroezemoes en lawaai gaan de passagiers aan wal.

Mijn detachement van 50 man, netjes in tenue op dek aangetreden, wordt buiten opgewacht door de militaire kapel. De oogen der kerels flikkeren, ze zijn in hun sas als ze de loopplank afgaan. Dan, onder de levendige tonen der muziek, en omstuwd door een drom van luidruchtig hossende jonge negerinnen, uitgelaten blij om de komst van nieuwe vriendjes, wordt, in brandende zon, opgewekt gemarcheerd naar Fort Zeelandia.

$$
\begin{aligned}
& \text { NAAR ALBINA } \\
& \text { (5-9 Jan. 1905) }
\end{aligned}
$$

Aan een korporaal van de kleine bezetting van Albina heb ik het te danken, dat ik zoo spoedig na aankomst in de kolonie, vergast word op een mooi reisje. De man had, op Fransch grond- 
gebied van een balling-libéré, een oude stakkerd, bij wien hij gedurende noodweer gastvrijheid had genoten, een broek gestolen, had die verkocht, enz.

Ergo een krijgsraadzaak. Als officier-commissaris krijgen een collega en ik order naar Albina te gaan tot het houden eener informatie.

Prachtig!

Tijdig ben ik aan boord van de „Curaçao", die, hoor ik, voor den vaart op de kust van Columbia was afgekeurd, maar goed genoeg bleek om geregeld de communicatie te onderhouden met Demerara en elders.

Met het oog op het getij vertrekt de boot om 5 uur n.m.

Het voordek is al vroeg vol; men vindt er schier al de Surinaamsche typen: bont gekleede negervrouwen die, hysterisch lachend, zich hajebajerig verdringen langs de reeling; naast hen min of meer fraai uitgedoste negers die, zwaaiend met de armen, een laatst adiosi schreeuwen naar de misies aan de wal; voorts Chineezen in gele, glimmende oliejassen, bedaard zittend op groote pakkisten, en doezelig turend met oogen die aan opium doen denken; Britsch-Indische koelies in sjovele plunje, den grauwen tulband losjes om het gebronsde hoofd, zijn schilderachtig neergehurkt in een hoek, teruggetrokken van al de anderen waar zij nimmer gemeenschap mede voelen.

De boot vertrekt, vaart rustig de breede, oker-bruine rivier af; de donkere oevers, met de plantage-woningen er wit plekkend tusschen, schuiven geleidelijk naar achter weg.

Als het fort Amsterdam is gepasseerd, duidt in het Westen de rossige vlammenlucht het slapen gaan der stille wouden. Onder een zalmrood licht siddert het water in opale tinten. Dan komt gauw de avond met zacht aandrijvende, ijle, donkere sluiers. Vooruit zien we, als een zwevende lichtring, het wakend oog van het 3 mijlen ver van de kust gelegen vuurschip.

Breeder en breeder wordt de watervlakte; wiegelend en schommelend heen en weer is de boot onmerkbaar de zee ingevaren; stampend, en djoekend met groote zuchten, worstelt zij tegen wind en baren. Op het volle voordek zwijgen spoedig de schetterende negergesprekken. Als een opkomende maan de golventoppen beglinstert, is het doodstil aan boord. Tot plotseling uit het vooronder mannenzang opklinkt ... de Marseillaise, daarna een ander Fransch lied, en nog een. Het blijken de wanhoopsliederen van een transport, naar Suriname gevluchte, maar weer gevangen genomen Fransche déporté's, die onder politiebewa- 
king, naar het bagno worden teruggestuurd. Het wordt kalm verteld, als een doodgewone zaak.

Ik ga even kijken.

Met ontzetting zie ik in het donker een massa menschen liggen, twee aan twee geboeid.

Wat moet er omgaan in de ziel van deze hopeloozen?

Zou ik dit tragisch moment ooit kunnen vergeten?

Den volgenden morgen tegen 11 uur wordt de vier K.M. breede Marowijne-monding ingevaren, links, op Fransch Guyana, bewaakt door den vuurtoren Les Hattes, rechts, achter het Tijgereiland, op de bocht van het vaste land, door het ijzeren Eifeltorentje Galibi ${ }^{1}$ ), dat onze vuurbaak is.

Machtig is de indruk van dezen geweldigen stroom.

Er schijnen veel zandbanken onder den waterspiegel te schuilen. Welig begroeide eilanden liggen coulisseachtig achter elkaar verspreid. Door het geruisch van de boot schrikken tallooze flamingo's en sabakoe's van de eenzame oevers op. Prachtig doet al dat rood en wit tegen het strakke blauw van de lucht als ze in groote zwermen wegvluchten naar den tegenovergelegen woudoever, om er, neerzwevende, een veiliger schuilplaats te zoeken tusschen de kronkelende luchtwortels der risophoren.

We varen aldoor vlak langs het Fransche grondgebied, omdat hier de diepste vaargeul ligt. Hoe stil is nu, hoe verlaten deze trotsche stroom. Geen boot, geen visschersschuit zelfs, is er op het immense, zonneblikkerend watervlak te speuren; ook de watervogels laten zich niet meer zien. De rommelende boot is het eenige levende orgaan op dit wijde, wijde meer. $Z_{\mathrm{ij}}$ stuwt het water kabbelend naar den oever tegen de rechte moko-mokosteelen, die enorme, hartvormige blaren dragen. De lichte zeebries doet alle palmenwaaiers even trillen, de waaiers der koninklijke Mauritiuspalmen, der lagere, maar elegante, dunstammige palissadepalm, der kolossale maripa- en der stekelige awarapalmen, die rijkelijk beladen zijn met groote trossen eivormige, gele vruchten. Telkens schittert in dezen, zich zelf ontwikkelenden, tropischen tuin, het fijne parwa-loof, dat overal in het land, langs de rivieren, den woudrand siert.

Zie, daar fladdert met onbedaarlijk gekrijsch een mooi-bonte ara op; hij kruist de wijde vlucht van den gier, de z.g.n. stink-

1) Met Galibi duiden de Franschen het Caraïben-ras aan; in de nabijheid van den toren bevindt zich een Indianen-nederzetting.

Zie W. I. Encyclopaedie, blz. 113. 
vogel, die boven de parwa-boomen in groote cirkels zweeft, loerend op een voor den mensch onzichtbaren buit.

Veel kreekjes met schilderachtige inkijkjes werpen zich in den grooten stroom. Hier en daar rijzen, tusschen het groen, hooge palen, waarop de telegraaflijn rust naar Cayenne. Op den anderen, verren Hollandschen oever, zien we, bijna geheel verscholen in den lommer van hoog geboomte, enkele met gedroogde blaren gedekte hutten van Indianen.

Eindelijk verschijnen, bij een lichte bocht, aan beide zijden van den stroom, groepen wit blinkende woningen in de verte, links Saint Laurent, rechts Albina. Waar in een hoogen parwa-boom aan den Franschen oever een witte houten driehoek hangt „la Dame blanche”, - wendt de boot resoluut den boeg, en stuurt recht op Albina aan.

Dit bekoorlijk gelegen grensplaatsje, gebouwd op een plek waar eertijds een Indianenkamp stond, dankt zijn oorsprong aan den gewezen onderofficier Kappler, die door zijn groote toewijding voor land en volk, de eerste is geweest die daarover waardevolle gegevens schreef; in Albina dreef hij een houthandel met de inboorlingen. Thans is hier de zetel van den districtscommisaris en van den geneesheer. Als station voor de goudzoekers in de Lawa telt het enkele toko's, die in handen zijn van Duitschers of Chineezen. Overigens geeft een detachement infanterie van circa 35 man eenige levendigheid aan het plaatsje. Het is een der gezondste plekjes der kolonie, maar het leven is er duur, omdat alles langs den langen waterweg uit Paramaribo moet worden aangevoerd; wat uit Saint-Laurent komt heeft het nadeel der inkomende rechten.

Uiterst gering is de bewegingsvrijheid op Albina; er is maar één weg, die landwaarts in naar met wouden begroeide hoogten leidt, maar die eigenlijk niet meer is dan een Indianenpad, in den regentijd onbegaanbaar. Alleen de soldaten maken er gebruik van, als zij Zondags voor ontspanning in de bosschen jagen gaan.

Maar Albina geniet dagelijks van twee voortreffelijke zaken: vooreerst is het muskietenvrij, bovendien is er een verrukkelijke, van pirin's - de blauwe rivierhaai - vrije badgelegenheid in een zandigen inham der rivier, koelend overschaduwd door zwaar geboomte; een kronkelend pad, met idyllisch hangend loof, leidt er heen.

Het interessantste is de ontmoeting van Indianen en Boschnegers. De eersten bewegen zich hier, in afwijking met de stad, 
waar zij min of meer gekleed moeten zijn, in hun natuurlijken staat. Opvallend bij dit natuurvolk zijn de kleine handen en voeten, de uiterst dunne polsen en enkels der vrouwen. De onderbeenen zijn, zooals veelal, geverfd met het roode koesoewésap.

Groot is het contrast met den magnifiek-krachtigen bouw der Joeka-Boschnegers, die vlak naast Albina hun nederzetting hebben. Superbe zijn bij de mannen de violet glanzende, forsch gebouwde tors en de sterk gespierde armen, die, in tegenstelling met de beenen, door het van jongsaf "parelen” tegen den snellen Marowijne-stroom, zich meer ontwikkeld hebben. Sommige jonge kerels, gelijk titanen, imponeeren als sculpturen van Michel Angelo. Hun vloot van lange corjalen, geduldig gehakt uit het rechte wana-hout, ligt op de zandige oeverhelling, gereed om direkt met hen af te glijden in den levendig bewegelijken stroom.

Het bejaarde hoofd van het kamp, een man met schrandere, schitteroogen, breeden neus en groote, wijduitstaande ooren, komt ons zijn opwachting maken. Den vorigen dag had ik deze autoriteit, die den kapiteinstitel draagt, naakt voor zijn hut zien zitten, zijn eenvoudig potje kokend op een rookerig houtvuurtje. Mijn verbazing is dan ook niet gering, als ik hem plotseling voor me zie in groot tenue, maar zóódanig, dat ik moeite heb om mijn noodzakelijken ernst te bewaren. Hij is deftig gehuld in een afgedankte uniformjas, met daaronder een witte onderbroek, bij gemis aan een behoorlijke wit linnen pantalon. Het hoofd is gedekt door een oud model koetsiershoed versierd met kokarde en witte struisvogelpluim, in de ooren glanzen zilveren knoppen, de bloote voeten steken in versleten gymnastiekschoenen. Zóó gevoelt hij zich werkelijk een man van beteekenis. Maar onze sabel en oranje sjerp steken hem zijn oogen uit; grinnekend drentelt hij om ons heen, tot eindelijk het groote woord er uit komt, dat hij, als kapitein, op dergelijke attributen meer recht heeft dan wij als luitenant ${ }^{1}$ ).

1) Bij een later bezoek met den Gouverneur van Asch van Wijck, deed zich een dergelijk incident voor. Het hoofd der Aucaner Boschnegers, de lastige potentaat Oseisie, was ter plaatse ontboden voor belangrijke besprekingen. Ook hij toonde groote afgunst voor mijn sjerp, en weigerde pertinent een onderhoud met Z.E., vóórdat hem een dergelijk kenteeken werd toegezegd. Eerst tegen den nacht kon deze autoriteit tot rede worden gebracht en de onderhandelingen een aanvang nemen. 
De reis naar Albina is vooral belangrijk door het bezoek aan de Fransche strafkolonie ${ }^{1}$ ).

Op den terugweg wordt nabij Galibi gestopt. Door de hooge branding is het landen niet eenvoudig, het is ondoenlijk de sloep naar den oever te brengen, zoodat we door de negerroeiers naar land worden gedragen. Merkwaardig is de z.g.n. Marowijnediamant die hier aan het strand gevonden wordt. De mooie exemplaren van dit heldere bergkristal worden, hoewel zij niet veel waarde hebben, in Amsterdam geslepen en in den handel gebracht. Ze zijn blijkbaar niet afkomstig van de hooger gelegen, bergachtige Marowijne-oevers, anders zouden zij ook in Albina of elders worden aangetroffen, maar van de rotsige kust van Cayenne, want zeestroom en branding spoelen ze wel aan op Galibi, maar niet op les Hattes.

$$
\begin{gathered}
\text { DE Wajombo } \\
\text { (5-7 Aug. 1895) }
\end{gathered}
$$

Het is vanzelf sprekend, dat bij den Gouverneur, die er nooit tegen op ziet om, door herhaaldelijk persoonlijk bezoek, land en volk zoo goed mogelijk te leeren kennen, het verlangen is opgekomen ook de gemakkelijk bereikbare, ongecultiveerde gedeelten der kolonie te bereizen ${ }^{2}$ ). Zóó is het plan gerijpt van een tochtje naar de goed bevaarbare Wajombo, een in het alluviale land ongerepte rivier, vallend buiten de gewone waterwegen, en waarlangs zelfs in de gouden tijden geen plantages hadden gefloreerd.

Wajombo... hoe mooi klinkt die naam die denken doet aan den sonoren klank van een bronzen gong.

Verheugd is een zeker aantal gasten, dames en heeren, in het vooruitzicht van een uitstapje naar een stuk oer-Suriname.

We vertrekken den 5den Augustus, 's morgens tegen zes uur met het stoomscheepje „Nederland”. Over een kalme zee wordt westwaarts gekoerst, tot we om half twee, bij de oude post Nas-

1) Het hierop volgende is weggelaten, omdat de strafkolonie en het strafstelsel door schrijver uitvoerig zijn behandeld in zijn artikel over „Het bagno in Fransch Guyana”, verschenen in ,,de Gids" van 1904 en 1905 .

2) Zes weken later mocht ik den Gouverneur vergezellen op een reis naar de Saramacca-rivier. In een overdekte sloep, gesleept door een stoombarkas, werd gedurende enkele dagen de stroom opgevaren, terwijl in medegenomen hangmatten, met daarnevens rookende vuurtjes ter afwering van muskieten, overnacht werd in een Boschnegerof Indianenkamp. 
sau, de breede monding van de Coppename invaren, om daarna de grootsche lijnzwaaiingen te volgen der door hooge wouden omzoomde oevers dezer uit het verre Zuiden komende, enorme stroom.

Ongeveer 50 K.M. van de kust stort de, uit westelijke richting aanvloeiende Wajombo haar water in de Coppename. Van haar bovenloop is weinig bekend; wel heeft Voltz haar tot den oorsprong gevolgd, maar hij bracht dit punt niet in kaart.

Zoodra we, 's middags om half zes, zachtjes de Wajombo zijn ingestoomd, voelen we, dat we de maatschappelijke wereld ver achter ons hebben gelaten, om gekomen te zijn in een oord waar de natuur, zonder inmenging van den mensch, al haar rechten gelden doet. Langzaam glijden we langs de eeuwig groeiende, massale wouden, die van de oevers uit, ondoordringbaar zijn. De hermetisch dichte, wilde woeker van diktouwige lianen, van welig struikgewas en warrelige klimplanten, vormt een haast onoverkomelijke borstwering.

We noemen dat de wildernis.

Hoe hard moet ook daar de tragische strijd zijn om het zelfbehoud van elken woudreus, van elke plant, van elk daartusschen levend dier. Zonder uiterlijk geweld is die eindelooze, rustelooze strijd, maar een strijd die niets ontziet, die geduldig maar boosaardig gevoerd wordt in een wereld van onzegbare stilte, een stilte grootsch, onverstoord en alomvattend, maar een stilte die verre is van die van een ons vertrouwd beukenbosch, van die onzer eenzame plassen of uitgestrekte heidevelden. Volkomen vreemd is die tropen-woudstilte aan onze intiemste instincten, zij is eer beklemmend dan weldadig. We merken het hier, geen onzer ontkomt, zij het onbewust, aan de hypnose van deze ongekende, oppermachtige geluidloosheid en zwijgzaamheid.

Roerloos is, in de laatste zonnestralen, het rossige groen der wouden, waarin we mysteries wanen; verlaten is het vlakke water, waarin de zacht voortglijdende boot enkele lange rimpels vouwt. Voor ons uit vlucht een vogel schichtig weg, scherend over den onbewogen stroom, om dan te verdwijnen in het veilige, reeds duisterende woud.

Het wordt avond; als in een droom varen we door een violette donkerte. Maar als we om acht uur het anker laten vallen tegenover het Indianendorp aan de Sipo-kreek, is de maan zoo vriendelijk ons te onthalen op een zeldzame feërie.

$\mathrm{Nu}$ wordt de verleiding groot om niet aan boord te blijven. In twee sloepen wordt geroeid tot het Indianen kamp aan de Oppo- 
tonno-kreek. 't Is er doodstil. Zou het kamp verlaten zijn? Welke wonderlijke sensaties bevangen ons in deze verre avondeenzaamheid.

Den volgenden morgen wordt om vier uur het anker gelicht; we varen de rivier op tot de Notto-kreek. Na zonsopgang wordt de dag warm, heel warm; het vurige zonneschijnsel pijnigt de oogen. Geluidloos gaan we door de vreemde, alles overheerschende stilte. Zwijgend kijken we naar de mysterie-wouden, de duistere, beangstigende wouden die nu, na onophoudelijke afwisseling van dood en verjonging, het zelfde machtige aspect hebben als honderden jaren her.

Op indrukwekkende wijze steekt de monumentale Mora excelsa, boven het overig zwaar geboomte, zijn geweldig bladerdak naar boven. Naast hem dingen de Mopé en de groenhartboom - deze met zijn vorstelijke kroon van goudgele bloemen - naar de oppermacht van het woud. Heel fijn teekent zich het loof van de wilde tamarinde af tegen de reusachtige blaren van de maripa. Dichter aan den oever toont de slanke palissadepalm de gracie van zijn bouw, wedijverend met de elegante palaloe, tusschen wiens breede bananenbladen een bloedroode bloem vurig fonkelt. Al het omringende groen nog brutaler te tarten weet echter het opvallend rood van de groote, wonderlijke, met heel lange, vermiljoene meeldraden gesierde bloemen van de boschcacao; ze zijn als een fantastisch vuurwerk tusschen het hoog geboomte.

Aan den waterkant spreidt, op een immense zuil, een lokus zijn enorme takken- en bladerstel uit. Met zulk een eerbiedwaardige majesteit beheerscht hij de gansche omgeving, dat de Indiaan dezen woudkolos als heilig beschouwt. Onder de reuzenarmen en onder het veilig dicht bladerdak bouwt hij bij voorkeur zijn primitieve woning, vertrouwend op den beschermenden geest van dezen oppermachtigen, magischen reus.

Een zeldzame sensatie, met avontuurlijk tintje, is het in deze volkomen geïsoleerde wereld den natuurmensch te bezoeken in zijn eenzaam gelegen kamp. Toch gevoelde ik iets als schennis; waarom deze verscholen menschen te verstoren door ons nutteloos geweld? Heeft onze aanraking met dit uitstervend ras iets bij kunnen dragen tot hun geluk, hun moreele rust? Heeft die zelfs kunnen leiden tot een noemenswaardige betere hygiëne en rasontwikkeling?

We bezoeken de, direkt bij het water gelegen Indianenkampen aan de Tittiebo- en Donderkreek. De bewoners weten drommels goed wie de beste leveranciers zijn van het voedzaamst en ge- 
zondste voedsel. De sjovele hutten immers zijn altijd omgeven door een kleine aanplant van cassave, bananen en bacoven, terwijl enkele papaja-boomen, met de pepsine-rijke, sappige vrucht, en napi's, een soort aardappelen, nooit ontbreken.

Bij onze nadering grommen de honden, de naakte kinderen schuilen schielijk weg. Als ik bij de Tittiebokreek een foto wensch te maken, trekt een der jongere vrouwen eerst een lang katoenen overkleed aan, de mannen verfraaien zich met een borstrokachtig kleedingstuk, dekken zich met neergeslagen, oude vilten hoeden. Eenigszins gekleed moeten zij in de stad verschijnen, daarom meenden zij, dat ik hen liever fashionabel op de foto had, dan alleen met de nationale kamisa, de tusschen de beenen door gehaalde lendendoek.

Aan de Donderkreek, dicht bij het punt waar de Wajombo doorde Arrawarra met de Nickerie-rivier wordt verbonden, is de woning van het kamphoofd voorzien van een verdieping met overdekte waranda. In het ruime voorvertrek vinden we, bij allerlei pijlsoorten, een groote trom, veelvormig vlechtwerk en met wonderlijke arabesken ${ }^{1}$ ) beteekende pagalen en waterkruiken, o.m. zoo waar een cellulose haarkam en spiegel. Behoort het ook tot de beschaving dezer primitieven om hen wat ijdelheid bij te brengen?

$\mathrm{Na}$ al het rustig zitten op het „Nederland”-dekje, doet het goed door het bosch te wandelen naar een ander Indianenkamp op de Savanne. Bij terugkomst aan boord wordt de terugreis aanvaard; 's avonds om acht uur wordt bij de Kalebas-kreek, die in de Coppename vloeit, voor anker gegaan; hier wordt overnacht.

's Morgens vroeg bij het gloren van den ochtend: de lange, in het water afhangende lianen, vangen het jonge, teere licht op; de toppen der hoogste boomen zijn als met goud overgoten koepels. Als langzaam de blauwige nachtdampen zijn weggetrokken, is het àl goud, de immense hemel, de ontelbare woudreuzen, het wijde watervlak, waarop gouden parels dansen. Bij een weldadige koelte is alles gehuld in een goddelijken glans.

Welk een verrukkend oogenblik!

Een oogenblik, want kort, heel kort duurt deze aardsche pracht waarbij het alles betooverend licht, mild zijn rijkste schatten schenkt. Nu het anker is gelicht en we de zoo vreemde, onverstoorbare rivierstilte weer gaan verlaten, schittert schel het da-

1) Later is gebleken dat deze arabasken geen willekeurige siervormen zijn, maar terug zijn te brengen tot totemistische voorstellingen. O.a. heeft Jhr. L. C. van Panhuys hierop meermalen gewezen. 
verende zonlicht over de ondoordringbare woudzomen en over het rimpellooze water; enkelen onzer wapenen zich weer met den grijzen zonnebril.

Nabij den mond van de Coppename wordt door den Gouverneur nog een droevig bezoek gebracht. Voor het laatst wellicht, want in overweging is genomen om de te ver afgelegen en vervallen leprozeninrichting Batavia - trouw beschermd door een Roomsch-Katholiek kerkje - naar elders over te brengen.

\section{CORONIE}

(29 Sept. - 2 Oct. 1895)

Er was voor den Surinaamschen dienst der Koloniale Vaartuigen een schoener gebouwd in Curaçao. Toen deze op de reede van Paramaribo aangekomen, er met zijn scherpen boeg zoo rank uitzag, terwijl het fonkelnieuwe van zeil en tuigage, van verf en betimmering deden denken aan een goedonderhouden millionnairs-plezierjacht, vatte de Gouverneur het aanlokkelijk plan op het fraaie vaartuig in te wijden met een inspectiereis naar het, tusschen de mondingen der Saramacca- en Nickerie-rivieren aan de kust gelegen Coronie-district.

Het blijft niet bij een plan, data worden vastgesteld, de noodige voorbereidingen worden uitgevoerd. Den beheerder der Koloniale Vaartuigen, een gewezen marine-officier, wordt het commando over het schip opgedragen; drie zeeofficieren van het wachtschip, worden met eenige dames en heeren, mede geinviteerd.

De zeereis is voortreffelijk.

Door het prachtige weer en een kalme zee, factoren die een uitmuntende stemming bevorderen, is het met recht een genoegelijk spelevaren.

De eerste moeilijkheden beginnen echter met de landing. Want door de vele modderbanken en door het, ten gevolge van voortdurende aanslibbing, tot ver in zee, zeer ondiepe vaarwater, is een nadering van boot of schoener tot aan de kust absoluut uitgesloten.

Wanneer in den scheepskijker de, als baak dienende, oude, hooge schoorsteen van de, sinds de opheffing der slavernij verlaten, maar vroeger zoo rijke suikerfabriek Burnside is waargenomen, laat de commandant het anker vallen. Geduldig wordt nu gewacht op den kotter, die steeds vóór het Gouvernementskanaal ligt om passagiers en lading wel niet direkt aan den wal - want ook dit is onmogelijk -, maar toch zoo dicht mogelijk bij den wal te brengen. 
Het overwippen van den schoener in den kotter heeft, door de geringe zeedeining, voor het vrouwelijk gezelschap geen al te groote bezwaren. De tegenstelling tusschen het plezierjacht en het simpele, aftandsche kottertje wordt ruimschoots vergoed door het genotvolle varen, en het kijken naar een onafzienbare menigte van flamingo's die de kust kleuren met een zacht rooden gloed, of die, met in de zon roodglanzend pluimage, in zwermen opvliegen van de modderruggen der Coppename-bank. Maar een feeërie wordt het, als ze dan neerstrijken in de mangrove-boomen langs de kust, waardoor de illusie wordt gewekt, dat we een tooverland naderen, waar de boomen getooid zijn met ongeloofelijk groote, roode wonderbloemen.

Dichterbij drijven rustig wilde eenden op de korte golfjes, wat verder wieken witte en jonge, grijze sabakoe's met langen vleugelslag over het hellichte water, terwijl talrijke strandsnippen zenuwachtig wegtippelen bij het naderen en daarna vastloopen van den kotter op het zand. De twee in de nabijheid wachtende, lange, smalle visschersschuiten, ieder bemand door een zestal stevige negers, komen nu langs zij om ons naar en door het kanaal eindelijk over te brengen naar den vasten wal.

Gaf op den tentloozen kotter het groote zeil nog eenige beschutting tegen de stijgende hitte, in de open schuiten, met allen dicht opeengepakt, is de laatste, vrij langdurige landingsétappe, zeker niet de aangenaamste. Maar de donkere bronzen roeiers met hun in de zon braaiende, zweetglanzende torsen, zorgen voor wat afleiding, niet zoo zeer ter wille hunner passagiers, maar om, door een rythmischen roeizang, de maat van den riemslag te regelen.

Eén begint: „Maskita béti mi na Jan Koiri passi, mi fréde”.

Muskieten bijten mij op den weg naar Gijersvlijt ${ }^{1}$ ), ik ben bang.

De anderen vallen in koor, bemoedigend-troostend, bij elken riemslag in:

„No fréde, no fréde, no fréde".

Wees niet bang, niet bang, niet bang.

Waarop de eerste, gerustgesteld antwoord:

„Mi no fréde, mi no fréde".

Ik ben niet bang, ik ben niet bang.

Dit wordt uitgegalmd in allerlei hooge en lage intonaties, totdat de man, als werd hij plotseling hevig door muskieten gepijnigd, gillend en met angst uithaalt:

1) De plantage Gijersvlijt wordt door de negers Jan Koiri genoemd. 
„Maskita béti mi na Jan Koiri passi”.

Als dit lied eenige malen herhaald is, is er een die er een eind aan maakt en met zware stem zingt:

„Dóisiman no sabi dem trànga,

Ingrisiman sa pori mi kóndre

Pe' dem man de"?

De Hollanders kennen hun kracht niet,

De Engelschen zullen mijn land bederven,

Waar zijn de mannen? (om dat tegen te gaan).

Vermakelijk zijn bij het zingen de telkens variëerende, mimische gelaatsuitdrukkingen, prachtig de musculaire werking van armen borstspieren bij het rythmisch trekken met de zware spanen. Op den duur blijkt dit alles geen voldoende attentie te trekken; mijn medepassagiers beginnen den zoo warmen tocht wel wat lang te vinden. We hebben evenwel geen reden van klagen: na het verlaten van den schoener zijn Jwe wel drie uur onderweg, doch 8, 10 zelfs 12 uur zijn geen zeldztá nheden bij tegenloopend getij. Vandaar de geïsoleerdheid vaverCoronie, dat van de landzijde door maagdelijk terrein en uitgestrekte zwampen ontoegankelijk is.

Lang voor onze aankomst waren de bewoners aan de landingsplaats samen gekomen. Bij het naderen der schuiten worden uit oude geweren saluutschoten gelost; een harmonica, trom en triangel - het negerorkest bij uitnemendheid - zorgen voor vroolijke welkomst-aria's. Bij het aan wal stappen barst een uitbundig gejuich los uit een groep, in koto-misi-dracht getooide vrouwen, schoten ratelen, gezang wordt luid aangeheven. Daarop gaat de gansche drom met de muziek, ons joelend vooruit. Maar de dichte stofwolken, die ons worden toegewuifd, zijn een benauwende hulde.

Op Leasones zijn de Hernhutter-kinderen onder de schaduw van een ouden manja-boom saamgekomen. De leriman leidt psalmgezang, vervolgens worden nationale liederen ten beste gegeven. De vraag is of deze naive negerspruitjes er ook maar eenigszins de beteekenis van voelen of begrijpen. Maar de keeltjes doen wel hun best, gelukkig dat het in de open lucht gebeurt.

Coronie gelijkt op een palmentuin; de 25 K.M. lange weg, evenwijdig aan de kust, is een haast ononderbroken, welige, palmenalleé, waarvan de sierlijk neigende kokospluimen den weg koelen schaduw schenken. Volgeladen zijn de boomen met dícht opeen getroste klappers die, glanzen als bronzen bommen.

Maar is hier welvaart? 
De ongeverfde, smerige negerkrotten aan den weg, in elkaar geflantst door middel van oude planken - timmerhout moet uit de stad worden aangevoerd - geven het antwoord. De slecht onderhouden woningen met oude loodsen van enkele plantages, sluiten zich hierbij aan.

Pôti Coronie, arm Coronie, vroeger zoo welvarend door bedrijvige, bloeiende katoen- en suikerplantages, vroeger, toen het mogelijk was dat velerlei repatriëerende Kegge's in Holland nog al wat in de melk te brokkelen hadden. $\mathrm{Zij}$ zouden verbleeken als zij nu terugkwamen in Coronie. Op de plaats waar hun winstgevende plantage stond, zouden ze povere negerkrotten vinden, de hooge schoorsteen van Burnside zouden zij herschapen zien in een droevige grafzuil. Waardeloos ligt nu Coronie's rijke bodem, de bewoner leidt, op den rijken grond, een armelijk, stuntelig bestaan.

Zou er dan geen toekoms meer zijn voor Coronie?

Het westelijk deel vanhe district: Oxford, Potori, Buckleburg, is rijk aan goede weilanden et gras zelfs in den drogen tijd. Het vee ziet er gezond uit, pra istig zijn de breed gehoornde stieren. Het landschap herinnert aan vaderlandsche weidestreken. Waarom zouden Hollandsche veeboer-kolonisten hier geen bestaan kunnen vinden? De arbeid is voor den veeboer niet te zwaar, het klimaat regelmatiger dan in Holland, de afdammingen en inpolderingen zijn niet gecompliceerd. De moeilijkheid schuilt hoofdzakelijk in de geïsoleerdheid van het district, wordt beweerd.

De oplossing zou gezocht moeten worden door, van Hamilton uit, den weg 30 K.M. te verlengen tot den Coppename-mond. Vee, gekoelde melk, enz. zouden verder binnendoor langs de Saramaccarivier, de Wanica-kreek en het Saramacca-kanaal (waarvan uitzicht op verbetering is door de plannen-Havelaar) naar de stad kunnen worden vervoerd op een waterwegafstand die niet grooter is dan die van Dordrecht naar Nijmegen. Men zou zich in de stad dan niet meer tevreden behoeven te stellen met het klein en mager Orinoco-vee, de boter zou goedkooper kunnen worden, terwijl de melk dan wellicht geen 30 cent de liter meer behoefde te kosten.

Vroeger werd reeds een aanvang gemaakt met een weg van Iengi kóndre naar de Saramacca; in 1888 werd daarvoor $f 10.000$ beschikbaar gesteld. Toen men tot de Koema-koemakreek was gekomen, werd het werk gestaakt, door verwachtingen der uitgraving van het Totness-kanaal. De zandbank vóór Coronie zal echter steeds een hinderpaal blijven voor den zeeweg. 
De inspectie in het district geeft ook ditmaal geen al te vroolijke resultaten. Langs den langen districtsweg geschiedt de tocht met den commissaris en enkele notabelen in oude, krakerige rijtuigjes, bespannen met schonkige biekjes. $\mathrm{Nu}$ begrijp ik eerst goed het roeierslied en de muskietenvrees. Zelfs overdag is de plaag buitengewoon irriteerend. Onder het rijden is het niet doenlijk de dicht opeengepakte muskietenlaag op de arme paardenlijven ook maar voor enkele oogenblikken te verdrijven.

Tijdens besprekingen in den tuin van den commissaris gedurende den vooravond, kunnen zelfs benauwd walmende kokosbasten ons niet veel baat geven. Zouden de zwampen, ten Zuiden van Coronie, de broeinesten zijn dezer triljoenen van plaaggeesten? Zoo ja, dan is de streek Hamilton-Coppename in dit opzicht wellicht veel dragelijker.

Pôti Coronie, het lijkt ons geen benijdenswaardig woonoord, geen land dat tot opgewekten arbeid stimuleert. De vroegere, krachtige bevolking is traag, sloopend is veel syphilis, die niet ten onrechte „mi njâm” — het vreet me op - wordt genoemd.

De terugreis op den mooien schoener, is verre van spelevaren.

Een orkaan raast zóó hevig, dat zelfs de zeeofficieren en een gedeelte der bemanning door zeeziekte worden neergeslagen. Met behulp van slechts drie man gelukt het den kordaten commandant om ons, na een angstvollen nacht, weer veilig in de Suriname-rivier te leiden.

\section{DE BOVEN-PARA}

(8 Nov. 1895)

Dit gemakkelijk bereikbare district is het meest loonend voor uitstapjes met veel afwisseling. Men reist per stoombarkas en met corjalen, men wandelt door laag- en door heuvelland, door bosch en savanne, de plantengroei heeft telkens een ander aspect, terwijl de bevolking van een geestdriftiger temperament is dan elders.

Per barkas is de tocht te maken door bij „Tout lui faut” de Suriname-rivier te verlaten en de Para-rivier op te varen. Wij gaan echter de Suriname hooger op, om even vóór „Groot Chatillon" de Doorsnede in te gaan, d.i. de rechte verbinding tusschen Suriname- en Para-rivier.

Even ten Zuiden van het punt waar de Doorsnede de Para bereikt, stappen we af aan het politie-station en dorp Onoribo, gelegen op een rood-zandigen, hoogen oever, en beschaduwd door enkele geweldig hooge can-cantree's en maripa-palmen. 
Te voren was de komst aangekondigd.

Een bezoek van den Granman - den Gouverneur - is voor de geheele Para-bevolking een waar feest. Er is voor haar dan gelegenheid om op de meest uitbundige wijze uiting te geven van haar trouw aan het Bestuur. Waar om zoo te zeggen maar één neger woont, zal deze niet nalaten om, bij het passeeren van den Granman op de rivier, al maar juichend, met zijn oud geweer een saluutschot te lossen. In de dorpen wacht de gansche bevolking, uitgedost in de beste kleeren, den Gouverneur en zijn gezelschap op met veel eereschoten der mannen, terwijl de vrouwen en dochters, in de bonte, wijduitstaande rokken, hotsend en dansend, gillend en zingend, den hoogen bestuurder tegemoet gaan, om, na uitbundig gewuif met de kleurig bebloemde hoofddoeken, deze, één voor één, in een langen looper, eerbiedig voor de voeten van den Gouverneur neer te leggen.

Een buitengewoon aardig huldebetoon!

De Granman schrijdt dan over den aaneengesloten hoofddoekenlooper naar de eerepoortjes van palmbladeren en bloemen en verder naar het dorp toe.

Zoo gebeurt 't o.a. in Onoribo.

De spontane geestdrift dezer kinderlijk-eenvoudige menschen is verrassend, zij treft ons allen. Maar bij al die uiterlijke geestdrift ontbreekt het ernstige accent niet. Aan de eerepoort is een groot bord bevestigd met de woorden:

„Da Gadoewoord da bergirots

Gods woord de bergrots.

A moe tan vodem.'

Leus: „Genade en Vrede”.

Daar waar de bevolking Hernhutters zijn, bestaat de welkomstzang hoofdzakelijk uit psalmen, door jong en oud zoo luid mogelijk uitgegalmd. De R.K. bevolking maakt gewoonlijk zelf een lied, dat door de vrouwen, al dansend om den Gouverneur, met blijheid wordt gezongen:

„Sinsi wi hábi wi Granman,

Sinsi Para libi boen,

Hé — hé — hé!

Wi Granman dè wi héde,

Sinsi ningre no kan bai ningre móro

Hé - hé - hé!

Wi Granman na wi bigi lóbi,

Móro moi man no dè na kóndre.

Hé — hé - hé!

West-Indische Gids XVI 


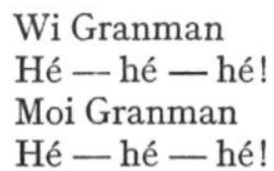

Sinds wij onzen Gouverneur hebben,

Is het leven goed in Para.

Sinds onze Gouverneur ons hoofd is,

Kunnen negers niet meer negers koopen.

Onze Gouverneur is onze groote liefde,

Een mooiere (betere) man is er niet in het land.

Het moeten gelukkige en tevreden menschen zijn die zóó met blijheid zingen kunnen en die, hoewel mondjesmaat levende van de karige opbrengst hunner kostgrondjes, dankbaar zijn voor de weldaden van het Bestuur. Treffend is ook de gulheid waarmede zij hun eenvoudige geschenken aan den Gouverneur bieden, bestaande uit cassave-koeken en eieren verpakt in fraai beschilderd blikwerk, prijkend met de spreuk:

Joe póri joe héde Joe kisi lóso.

Wat woordelijk vertaald zeggen wil: als ge het hoofd niet verzorgt, krijgt ge luizen, oogenschijnlijk een wel erg belachelijke raad voor Z.E. den Gouverneur. 't Is echter symbolisch bedoeld, de diepere zin is deze: als ge slecht zijt tegen je hoofd (van het land), krijgt ge moeilijkheden.

$\mathrm{Bij}$ het vertrek wordt weer veel geschoten, veel gezongen, veel gejuicht en veel gewuifd met de intusschen weer opgeraapte bonte hoofddoeken.

Ik hoor vertellen dat, in afwijking met de overige negerbevolking, in de Para een soort veelwijverij bestaat, als gevolg van het feit dat, wanneer de vrouw zeker weet wachtende te zijn, zij haar man niet meer bij zich duldt. Het gevolg is, dat de man elders andere vrouwen zoekt. Gaat hij uit werken, houtkappen b.v., dan vindt hij hier en daar gemakkelijk een tehuis, omdat bij de Paravrouw de zucht bestaat naar een zoo groot mogelijk aantal kinderen, ten einde van deze steun te krijgen wanneer zij op een leeftijd is gekomen dat zij niet meer baren kan. Dan immers wordt zij bespot en zelfs als dood verklaard. Daarom is een vrouw die nimmer heeft kunnen baren, een ware ongelukkige.

Hooger de Pararivier opvarende, wordt gestopt bij Triangel, de plaats waar de Coropine in de Para valt. Hier waren, met het oog op het ondiepe water, corjalen besteld. Gelukkig schikken 
de dames zich best in het lange, smalle negervaartuig bij uitnemendheid.

De tocht wordt, de Coropine Zuidwaarts opvarende, verder voortgezet naar Bersaba en Post Republiek. Het minst bezwaarlijk is deze reis te maken in het begin van den droogen tijd, men heeft dan geen last van regen, terwijl de riviertjes toch voldoende vaarwater hebben. Het verschil in waterstand in den droogen en natten tijd kan ruim $2 \mathrm{M}$. bedragen.

Zeer aantrekkelijk en hoogst aangenaam is de corjaalvaart.

Met gelijken „parel”-slag der roeiers glijdt het ranke vaartuig onhoorbaar en vlug door het stille, opmerkelijk donkere water. 't Is daarbij een genoegen te zien naar het, door de gespierde kerels, stijlvol hanteeren van de pagaai, die loodrecht met het ondereind in het water komt, dit krachtig wegduwt en dan rechtstandig er weer wordt uitgehaald.

De oevers zijn hoog begroeid met wilde papaja, aronskelkachtige moko-moko, stekelige kiskissi- en boegroemakà, waarover weer de wilde markoesà zijn randen slingert; we grijpen naar de gele, smakelijke vruchtjes. De takken van de boomen der beide oevers zijn zoodanig als een langen tunnel in elkaar gestrengeld, dat we heerlijk beschut worden tegen de felle zonnestralen. Libellen trillen met transparante vleugels boven het water, exotische kapellen zweven her en der. Deze tropische gondelvaart wordt na $11 / 2$ uur onderbroken door de aankomst in Bersaba, standplaats van den leriman. Hij heeft hier aan den oever een eenvoudig kerkje, met een woning er naast. Vlak bij ligt het landelijk dorp, waar we met veel gekwaak van eenden en doksen worden verwelkomd.

Een weinig hooger op wordt geland op Republiek, in den bloeienden plantagetijd een militaire post met een bezetting van 1 officier en 25 à 30 man, wakend tegen het wegloopen van baloorige slaven. Nu is Post Republiek politiestation, en de standplaats van den districtsgeneesheer. Verlaten en stil is het hier op de kleine savanne.

Iets Zuidelijker passeeren we de houtonderneming ,,Vier Kinderen", waar het groote gebouw der R.K. geestelijkheid opvalt; er is een kerk in, een school en een woning voor twee paters. Over het in den slaventijd met veel rietslagen aangelegde Wanica-pad, is er noordwaarts met de stad een behoorlijke verbinding, die langs het rijkelijk met kokospalmen beplant dorp Onverwacht leidt. Zuidwaarts voert de weg naar het drie uur verder gelegen dorpje Berlijn, met een tak naar Rama aan de Suriname- 
rivier. Hoewel van de goudvelden uit deze weg benuttigd zou kunnen worden, wordt toch de waterweg verkozen.

Tusschen Republiek en Berlijn zijn de gedeelten van den weg door het bosch het best; zij zijn breeder, koele schaduw vloeit neer uit het dichte bladerdak. Die blaren zijn dik en metalig, zij zijn bestand tegen den brand der zon en tegen de agressieve regens. Onder den dom van de bolletrie, de kopi, de groen- en purperhart-boom, prijken tal van palmsoorten.

Bronskleurige kreekjes zorgen voor de irrigatie; met pluimige varens zijn de kanten gesierd. Vreemd is de klanklooze, diepe stilte. Tot opeens het helder, zuiver geluid van een verschrikte vogel klinkt.

We zijn met te velen om intens de mysterie-stemming van het tropenbosch op ons te doen inwerken, of om het ook maar eenigszins te bespieden in zijn gedaanten van plant en dier, om geheimen te ontdekken die we allerminst bevroeden zouden. Toch schenkt zij zeldzame sensaties die wandeling door het wilde bosch, waar tusschen de gracie van veelsoortige palmen en de weelderig hooge varens, allerlei wonderlijks zou kunnen gebeuren.

Maar alle zweem van droomerij wordt onmiddellijk weggevaagd, als we het bosch verlaten onder het krijtend wegfladderen van een groep papegaaien, en dan de verblindend lichte, schroeiend heete savanne, wijd voor ons zien uitgestrekt. De weg, overwoekerd dorr het hooge, grove savanne-gras, versmalt zich spoedig to tot ${ }^{+}$ een pad, dat we à fil d'Indien moeten volgen, met achteraan de drager van het kostbare, koele drinkwater. Af en toe moet het pad over het heuvelachtig terrein door wegkapping worden vrijgemaakt. Het suikerwitte, heldere kwartszand kaatst stovend de vlammende zonnehitte terug. Enkele vorstelijke Mauritiuspalmen, waarvan de bijna recht omhoog geheven reuzenwaaiers scherp silhouetteeren tegen den puren, kobalten hemel, bieden rustpunten tusschen het blikkerend, dor-gelige, wilde Para-gras.

Ten slotte wordt, met een ander stel corjalen, langs de Pararivier van Berlijn over Eendracht en Hannover, de terugreis naar Triangel aanvaard. Mika-schilfers flikkeren op den zandigen bodem van het bronskleurige water. Onhoorbaar glijden de ranke vaartuigen in den lommer van weelderig geboomte, waar hier en daar, hoog en onbereikbaar, purper-roode en witte or hideën verleidelijk hun kostbare pracht verspreiden.

In Triangel wacht de stoombarkas, die verder de Para-rivier afzakkend, ons via „Tout lui faut”weer naar destad terug brengt. 
UIT EEN OUD DAGBOEK

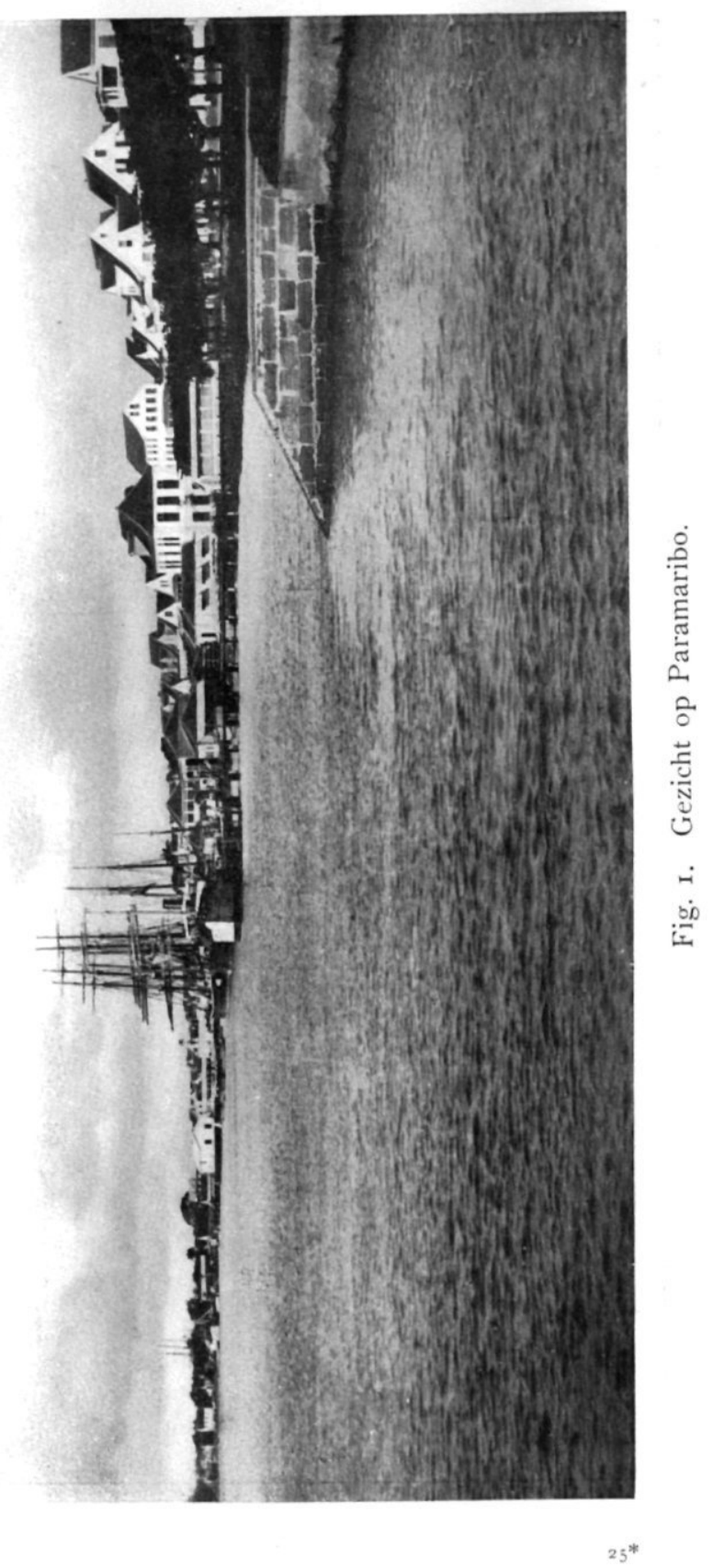




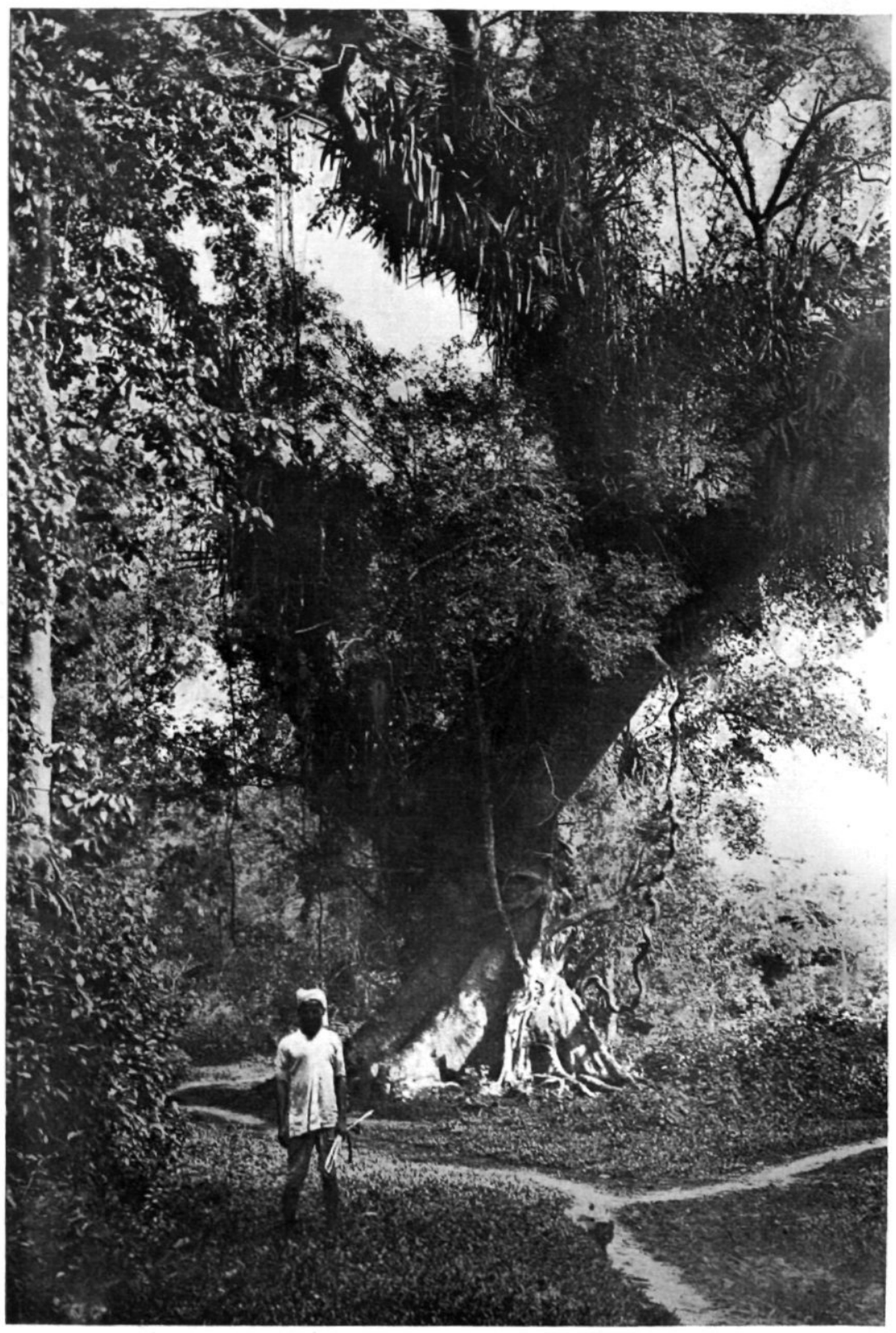

Fig. 2. Can-cantree. 


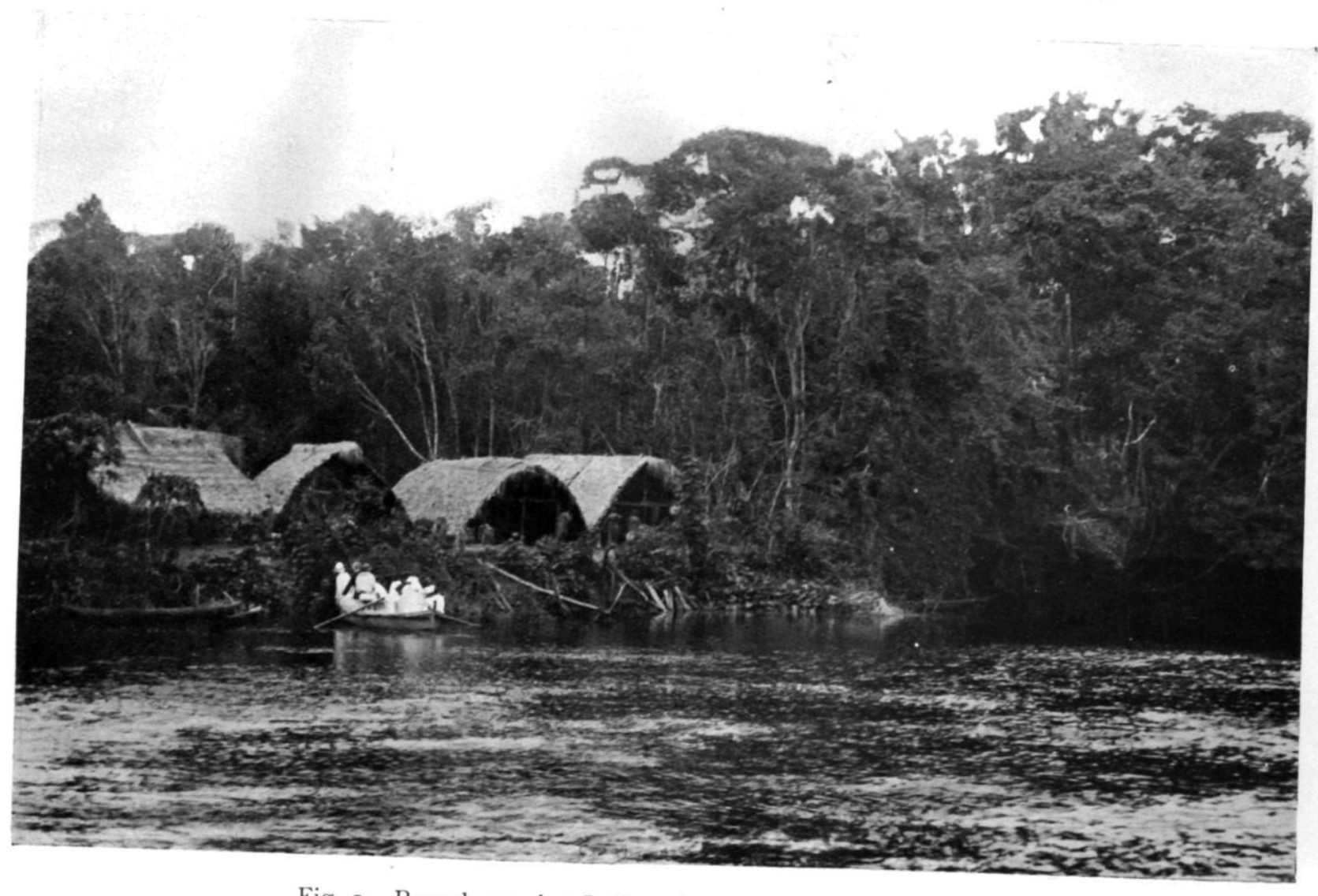

Fig. 3. Bezoek aan het Indianenkamp aan de Tittiebo-kreek. 


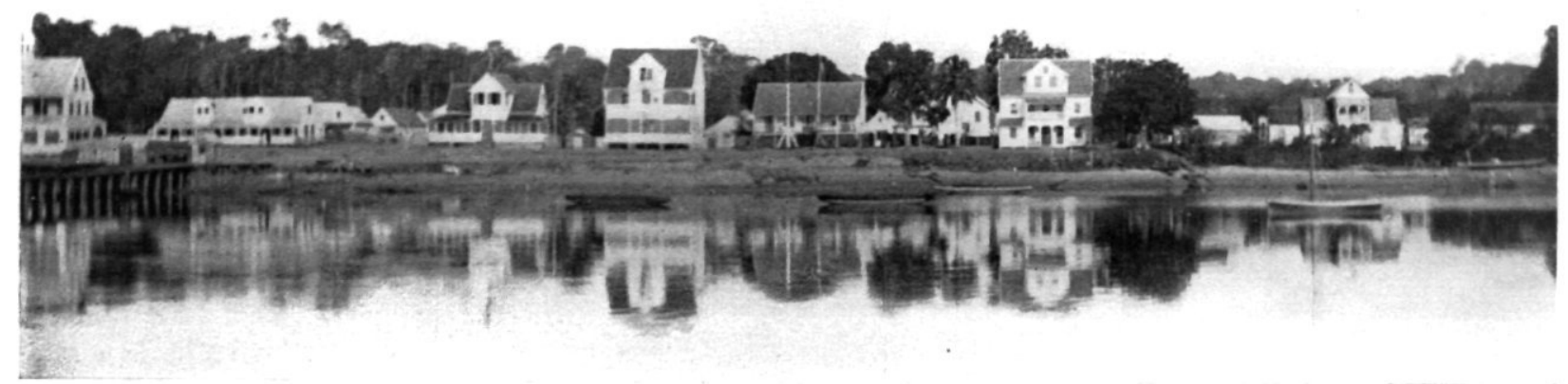

Fig. 4. Albina.

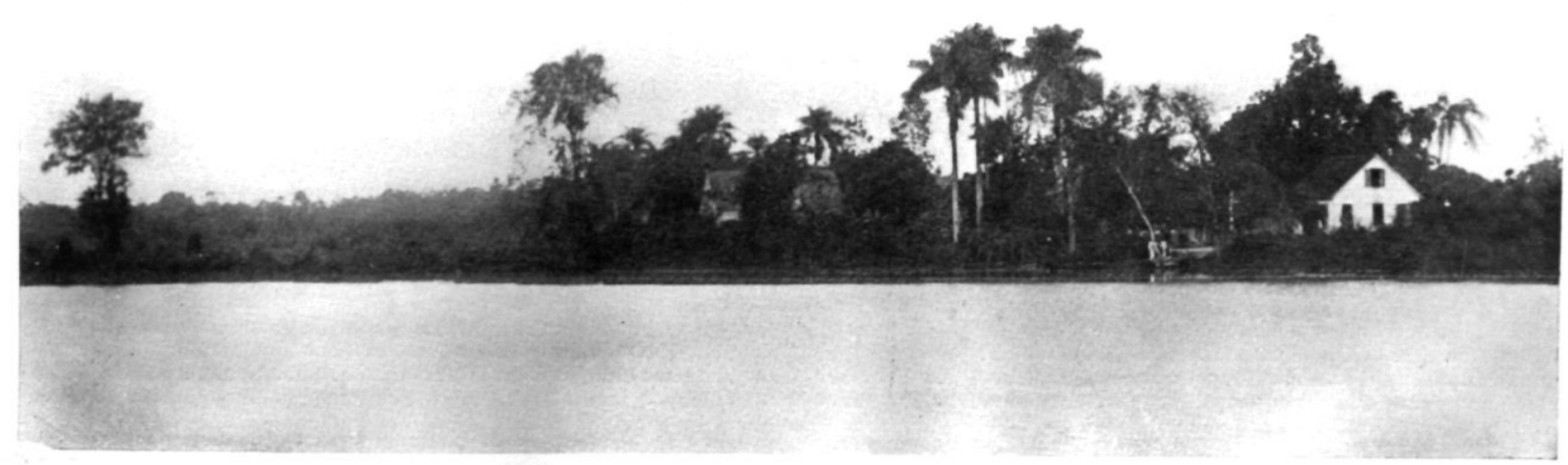

Fig. 5. Het (later verlaten) leprozengesticht „Batavia”, aan den Coppename-mond. 